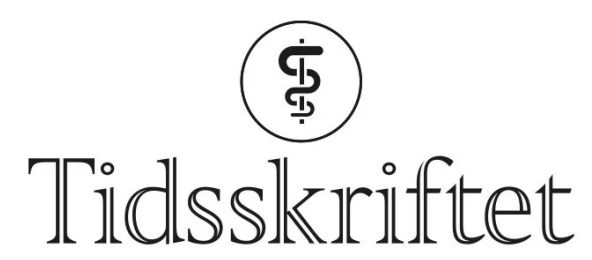

DEN NORSKE LEGEFORENING

\title{
Svært spesielt om diabetes
}

\author{
ANMELDELSER
}

JAK JERVELL

Oslo

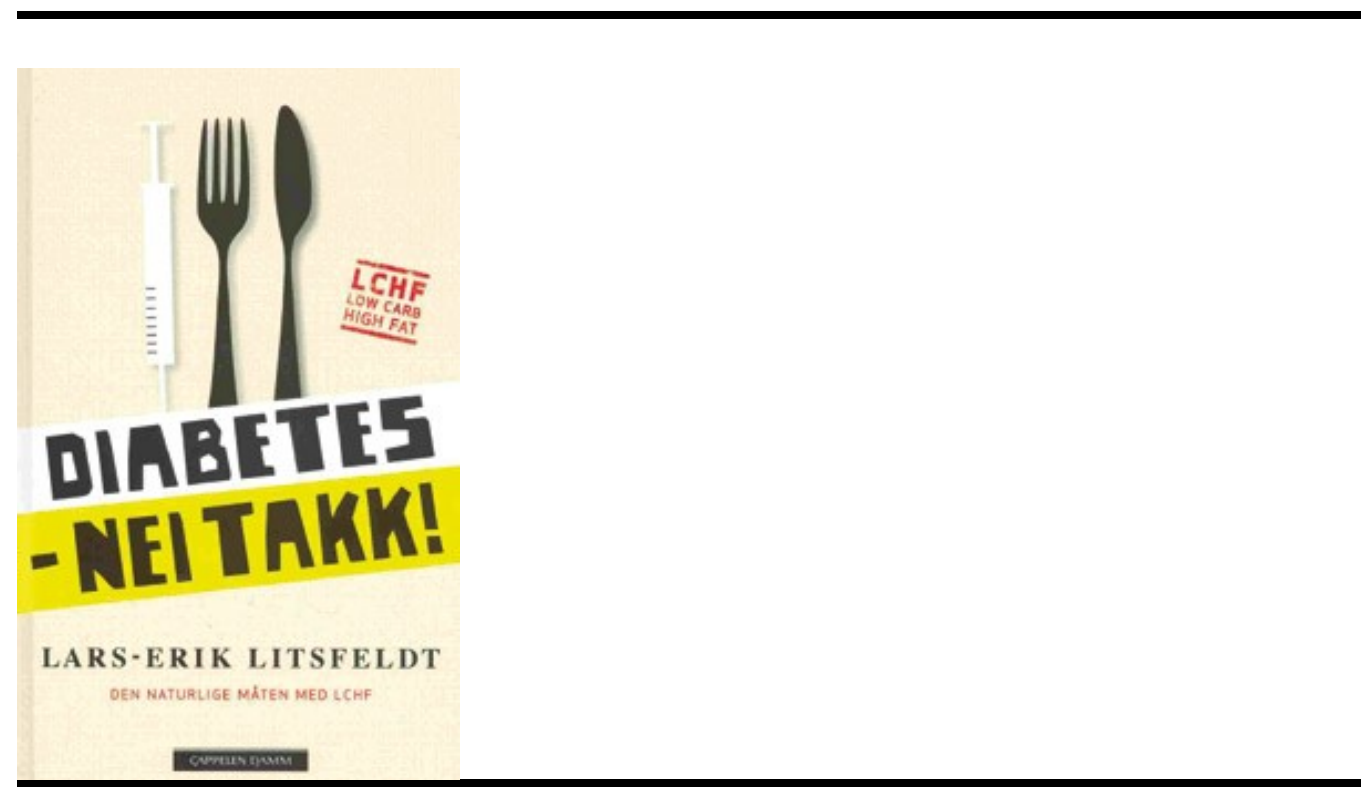

Litsfeldt, L-E.

Diabetes - nei takk!

Den naturlige måten med LCHF. 153 s, ill. Oversatt fra svensk av Mette-Cathrine Jahr. Oslo: Cappelen Damm, 2010. Pris NOK 269

ISBN 978-82-02-30852-0

LCHF stammer fra engelsk og er en forkortelse for low carb high fat, og brukes som en enkel forkortelse for et kosthold som noen anbefaler, både som en enklere metode til vektreduksjon og til behandling av type 2-diabetes. Basert på egne erfaringer går forfatteren inn for et kosthold med ekstremt lite karbohydrater og svært mye fett.

Behandling av type 2-diabetes er imidlertid mye mer enn blodsukkerbehandling. Hensikten med behandlingen er et godt liv, og også et langt. Siden mennesker med type 2diabetes har høy dødelighet av hjerte- og karsykdom, rettes mye av behandlingen mot risikofaktorene for koronarsykdom, med såkalt hjertevennlig kost; heller umettet enn 
mettet fett. I de nye nasjonale, kliniske retningslinjene for diabetes er det satt opp følgende behandlingsmål: røykeslutt, moderat fysisk aktivitet (minst 30 minutter daglig), alle overvektige bør prøve å oppnå et vekttap på minst $5 \%$, ønsket verdi for $\mathrm{Hb} \mathrm{A}_{1 \mathrm{c}} \leq 7 \%$, man bør tilstrebe et blodtrykk $\leq 135 / 80 \mathrm{~mm} \mathrm{Hg}$, og man bør tilstrebe et LDL-kolesterol $\leq 2,5$ $\mathrm{mmol} / \mathrm{l}$ (B) og $\leq 1,8 \mathrm{mmol} / \mathrm{l}$ hvis det foreligger koronar hjertesykdom (1) .

Litsfeldt anbefaler et ekstremt kosthold. Spesielt ble jeg imponert av Litsfeldts frokost: «Om morgenen er det hensiktsmessig å spise egg. En fin måte å få i seg mye fett på og begrenset med protein, er å la noen av eggehvitene gå i søpla. Stekt bacon i småbiter i smør, og når de er ferdige, heller du over eggene vispet sammen med en skvett fløte. Eggerøren suger opp fettet i stekepannen. Serveres med en klatt smør som får smelte oppå alt sammen - da får eggerøren vinger. Med en slik frokost har du gode forutsetninger for å klare deg uten noe mellommåltid om formiddagen. Ikke spis noe fullkornbrød».

En slik diett gjør kanskje at man mister appetitten og derfor går ned i vekt. Type 2-diabetes skal man imidlertid ha resten av livet. På sikt kan derfor ikke slike ekstreme kostendringer anbefales, det vil vanskeliggjøre normale sosiale aktiviteter. Har man pasienter som ønske å prøve LCHF, bør man gi råd om ikke å øke mengden mettet fett og følge med på lipider, blodtrykk og vekt. For leger er boken interessant, mest fordi den er så spesiell, og i tillegg ganske godt skrevet. Jeg vil imidlertid ikke anbefale den til folk som har diabetes.

\section{LITTERATUR}

1. Claudi T, red. Diabetes: forebygging, diagnostikk og behandling. Nasjonale kliniske retningslinjer. Oslo: Helsedirektoratet, 2009.

www.helsedirektoratet.no/vp/multimedia/archive/oo113/Diabetes (26.5.2010).

Forebygg_1136oga.PDF

Publisert: 1. juli 2010. Tidsskr Nor Legeforen. DOI: 10.4045/tidsskr.10.0526

(C) Tidsskrift for Den norske legeforening 2023. Lastet ned fra tidsskriftet.no 26. april 2023. 